\title{
DEMETRIO MATAFARI, BISHOP OF NIN (C. 1315 - 1375) AND HIS AFFAIRS WITH THE APOSTOLIC CAMERA : THE CASE OF HIS MOVABLE PROPERTY INVENTORY
}

\author{
Jadranka Neralić
}

\author{
J. Neralić \\ Hrvatski institut za povijest \\ Opatička 10 \\ HR-10000 Zagreb \\ neralic@yahoo.it
}

\begin{abstract}
The case of Demetrio Matafari (c. 1315-1375), bishop of Pedena (Picanj) in Istria (1345-1354), suffragan of the Patriarch of Aquileia, and bishop of Nin in Dalmatia (1354-1375), and his problems with the Apostolic Camera residing in Avignon, entered the European ecclesiastical and cultural historiography fourty years ago. The short entry in a repertory compiled from the Cameral funds of the Vatican Secret Archives of almost 2000 cases of spoliation of deceased clerics' movable property during the Avignon Papacy, did not receive much scholarly attention in Croatian historiography ever since. Parallel study of the prevalently unpublished sources from the Vatican Secret Archives, as well as the documents from Aquileian and Dalmatian archives have unveiled another outstanding fourteenth century bishop's career. Member of one of the most illustrious fourteenth century Zaratine noble families Demetrio Matafari travelled throughout Europe visiting papal courts in Avignon and Rome, collaborated with cardinals, apostolic legates and collectors, patriarchs and bishops in the North-eastern Italy. At the end of what seemed to be a successful ecclesiastical career, highly indebted with the Apostolic Camera he had to face the confiscation of his own movable property and revenues of his diocese.
\end{abstract}

Key words: Apostolic Camera, Avignon Papacy, collectors, right of spoil, inventory, movable property, testamentary license, ecclesiactical career, Dalmatia, Demetrio Matafari

Historians of medieval or early modern economy, culture or society attending the Vatican Secret Archives can find useful information in the variety of official records scattered through particular archives of different Curial departments, such as Apostolic Chancery, Apostolic Camera (Camera Apostolica), Dataria, or Sacred Roman Rota, Sacred Penitentiary. In the absence of exhaustive inventories which would help find the needed and desired documents, each researcher necessarily makes his own hunt through the pages of registers relevant to his subject, territory, period or person. In the decade and a half from 1974 to 1988 Daniel Williman published three monographs with the repertories of his exhaustive researches conducted in the archives of the Apostolic Camera within the Vatican Secret Archives during the 1970ies. The first part of The Right of Spoil of the Popes of Avignon 1316-1415 published in $1988^{1}$ provides useful introductory definitions of the papal ius spolii, details of the development of this practice, its relation to existing canon law and canonical scholarship, information on administration and documentation of spoils, extent and incidence of the papal right of spoil, and the final curbing of spoliation. However, its greater part consists of a repertory of 1,191

\footnotetext{
${ }^{1}$ D. WILLIMAN, The Right of Spoil of the Popes of Avignon 1316-1415. Transactions of the American Philosophical Society. Held at Philadelphia for Promoting Useful Knowledge. Volume 78. Part. 6. Philadelphia 1988.

${ }^{2}$ Id., Records of the papal right of spoil 1316-1412. Institut de Recherche et d'Histoire des Textes. Bibliographies. Colloques. Travaux préparatoires. Paris, Centre National de la Recherche Scientifique, 1974.
} 
individual spoil cases in the various register series of the Apostolic Camera. This was a revised and expanded edition of the repertory contained in his Records of the Papal Right of Spoil, 1316-1412 published in $1974^{2}$ together with a whole range of fuller indexes. In the book Bibliothèques ecclésiastiques au temps de la Papauté d'Avignon professor Williman published his researches on the cases of spoliation of ecclesiastics - cardinals, archbishops, bishops and minor clerics, whose libraries became the object of spoliation for the Apostolic Camera after their death in the period of the Avignon papacy. ${ }^{3}$ Among 1,149 cases collected in 1974, and almost 2,000 included in his third book, several are related to the ecclesiastical persons from Dalmatia. Cronologically, the earliest case refers to the library of the Augustinian monk John, former bishop of Senj (1333-1348) and archbishop of Split (1348-1349), who died in Pisa before 3 March 1349, whose eight manuscript books were collected for the Apostolic Camera in the Augustinian monastery of St. Nicholas in Pisa by the apostolic collector in Tuscany, prior of the Augustinian monastery of St. Paul ad Ortum and the decretorum doctor Andreas de Tuderto. ${ }^{4}$ Williman's exhaustive repertory of cases of spoils also includes the cases of Dominican friar Jacobus de Corvo, former bishop of Zagreb from 1322, bishop of Toulon from 1330, who died in 13415; Augustinian monk Joannes Morosini, bishop of Cittanova in Istria from 12 February 1347, who died before 15 March 13596; of the Dominican friar Benedict, bishop of Pula in Istria from 18 January 1358, former bishop of Sora from 13 September 1344, and of Chioggia from 26 January 1348, who ${ }^{3}$ Id., Bibliothèques ecclésiastiques au temps de la Papauté d'Avignon. I. Inventaires de bibliothèques et mentions de livres dans
les Archives du Vatican (1287-1420) - Répertoire. II. Inventaires de prélats et de clercs non français - Édition. State Univer-
sity of New York at Binghamton. [Documents, études et répertoires publiés par l'Institut de recherche et d'histoire
des textes], Paris 1980.

${ }^{4}$ Id., Records..., p. 117, n 592; Id., Bibliothèques..., p. 46, 191 n 349.2. Id., The Right of Spoil ..., p. 155, nº 614; Papal letter dated 27 December 1348, addressed to Andrea de Tuderto with the commission to compile the inventory of movable property as well as the debts and incomes of the deceased archbishop of Split, and to send the redacted document to the Apostolic Camera was registered in: Archivio Segreto Vaticano (hereafter: ASV), Reg. Vat. 142, f. 118v, ep. 620, and Reg. Vat. 244-L, f. 61r, ep. 171. See: E. DEPREZ - G. MOLLAT, Clément VI (1342-1352) lettres closes, patentes et curiales intéressant les pays autres que la France publiées ou analysées d'après les registres $d u$ Vatican. Paris 1960, $\mathrm{n}^{\circ}$ 1884. A. THEINER, Vetera monumenta Slavorum meridionalium historiam illustrantia, maximam partem nondum edita ex tabulariis Vaticanis deprompta, collecta ac serie chronologica disposita. Tomus I. Ab Innocentio papa III usque ad Paulum papam III. 1198-1549. Romae et Zagrabiae 1863-1875, p 222, n 295. Apart from the list of eight books published by professor Williman, the receipt issued by the Apostolic Camera contains the following deceased archbishop's property, received by the collector from the prior of the Pisan convent: In nomine Domini. Amen. Infrascripta sunt res quas venerabilis vir dominus Andreas de Tuderto, decretorum doctor, prior sancti Pauli ad Ortum, sedis apostolice nunctius et collector in Tuscia, habuit et recepit de bonis que reperta fuerunt in ecclesia sancti Nicolai de Pisis, conuentus fratrum ordinis Heremitarum sancti Augustini et sibi nomine Romane Ecclesie et eius Camere tamquam de bonis que remanserunt domini condam fratris Iohannis archiepiscopi Spaletansis Camere apostolice reseruatis, assignate et tradite fuerunt per fratrem priorem tunc dicti ordinis et conuentus videlicet: In primis pancalia tria cum pampinis et babornis diuersorum colorum. Item sargia vna a lecto catabriata. Tobaleole quinque ad manus. Tobalee pro tabula tres antique. Tobaleoli ad uultum parui quinque. Linteamen vnum. Stagnate pro vino tres. Misciroba de cupro vna. Camiscia vna cum duobus serabulis. Salecte duo de stagno. Branche due de corallo cum veriis de argento et duo ferri cultellinorum. Duo parua instrumenta ad commiscere dum crisma cum casella de cono. Coclearia duo de argento. Tappetum vnum paruum. Brilgiam unam pro equo. Vnum par calcarium. Item librum vnum appostillarum super epistolas. Omelie Beati Gregorii super Eçechielem. Summa de vitiis et uirtutibus. Librum vnum de virtutibus et de immagine mundi et contemplatione. Liber sermonum dominicalium et festiuorum. Liber sermonum quadragesime super epistolas et euangelia. Liber paruus sermonum in cartis papiri. Liber quidam ubi sunt diuerse medicine. Quedam carte nacue et non scripte cum quibusdam quaternis scriptis. Vacchecta vna de papiro in qua nichil est scriptum. Scabellum vnum. Item cassa vna de ligno in qua erant res supradicte. Quas quidem res dictus dominus uel dicto nomine penes se habere et remanere confessus fuit. Actum Pisis in sacristia ecclesie sancti Nicolai Pisis, conuentus dictorum fratrum presentibus et rogatis testibus domino Rainerio priore Sancti Sixti Pisano, Galasso Vansini de Laterino, Vannucio Berardi de Tuderto et Francisco Balere de Sancti Miniate, testibus ad premissa. Sub anno natiuitatis Domini millesimo tricentesimo quadragesimo nono, indictione secunda, die tertia Martii, per cartam mandati ser Nicolai Andree de Nibleis de Parma notarii.

${ }^{5}$ WILLIMAN, The Right of Spoil..., p. 151, n. 589.

${ }^{6}$ Id., Records..., p. 128, n 658; Id., The Right of Spoil ..., p. 71, n' 128. 
died before 17 April $1360^{7}$ and the archdeacon of Šibenik Radolfanus ${ }^{8}$ whose property was collected by the bishop of Padua Raimondo Ganimberti (23 January 1374 - late 1386, translated to Marseilles early in 1387), collector of debts for the Apostolic Camera in Lombardy in 1374 .

However, the most interesting Dalmatian case in the Williman's books is that of «Demetrius de Matafaris, bishop of Knin in Dalmatia, died before 17 August 1367. Bishop of Pedena in Istria from 1345: of Knin from 22 February 1354.» The record on his spoil case - the «quittance to Bertrandus Ebrardi, who assigned the goods to the Camera in Rome» was taken from the register preserved in the series Collectoria 353, ff. 133v-134v of the Camera Apostolica archives. ${ }^{10}$ With these entries in professor Williman's books Demetrio Matafari was launched into the European ecclesiastical and cultural historiography. However, although most of his lifetime he remained in the shadow of his elder and more famous brother Nicolò Matafari, student of the best canonist of his time Giovanni d'Andrea, who was appointed archbishop of Zadar by Pope John XXII in $1333^{11}$, almost thirty years long career as bishop in two dioceses on the Eastern Adriatic coast and his active engagement in the service of the Apostolic Camera certainly deserve a more exhaustive biography.

Demetrio belonged to one of the most influential fourteenth century noble Zaratine families. His father Guido, who died between 20 October and 28 December 1333 ${ }^{12}$, had four sons (Vučina, Nicolò, Ivan ${ }^{13}$, and Demetrio) and a daughter Fumia. Like her two brothers Nicolò and Demetrio, Fumia also embraced the ecclesiastical career. In the 1340ies she was a nun in the Benedictine nunnery of St.

\footnotetext{
${ }^{7}$ Id., Records..., p. 28, n 126; Id., The Right of Spoil ..., p. 165, n 682.

${ }^{8}$ ASV, Cam. Ap., Collect. 129, f. 247v: Sequitur de spoliis et fructibus temporibus vacacionum: Millesimo III' LXXIIII ${ }^{\text {to }}$ recepi a Blandica commissario condam Radolsaui(!) olim archidiaconi Sibinicen. de bonis dicti archidiaconi defuncti ducatos duodecim. Item de fructibus dicti primiceriatus ducatos duos auri.

${ }_{9}^{9}$ WILLIMAN, Records..., p. 188, n 975.

${ }^{10} \mathrm{Id}$., o.c., p. 50, $\mathrm{n}^{\circ} 239$. The record published in the Bibliothèques..., p. 237, $\mathrm{n}^{\circ} 367.6$ repeated the erroneous name of the bishopric (Knin instead of Nin) and the date of presumed death of Demetrius de Matafaris, but the list of 9 books, which the apostolic collector Bertrand Ebrard assigned to the Apostolic Camera in Rome, was added.

${ }^{11}$ The last archbishop of Zadar Johannes de Butuane died in Zadar on 6 April 1333; only five months later, from Avignon on 10 September the canon of the Warad cathedral chapter (in close relations with the Hungarian royal house of Anjou), Nicolò Matafari received the papal appointment. ASV, Reg. Vat. 107, ff. 1v-2r, ep. 2; G. MOLLAT, Jean XXII (1316-1334) Lettres communes analysées d'après les registres dits d'Avignon et du Vatican. [Bibliotheque des Ecoles Françaises d'Athènes et de Rome], Paris 1904-1947, n 61371; THEINER, o.c., p. 188-189, n² 248; T. SMIČIKLAS, Codex diplomaticus Regni Croatiae, Dalmatiae et Slavoniae. Zagreb, vol. X (1912), p. 118-119, n. 77, and the relative dispensation de defectu ordinum in litteris promotionis suae non factae, since he did not receive ecclesiastical orders, dated 13 September 1333. ASV, Reg. Vat. 107, f. 255r, ep. 784; MOLLAT, n 61377, THEINER, o.c., p. 189, n² 249. Still in Avignon on 2 October Nicolò promised to pay 400 florins as his common services fee to the Apostolic Camera: ASV, Cam. Ap., Oblig. et Sol. 6, f. 129v. On 6 May 1334 the Archbishop was (still!) in Avignon, as he personally paid one hundred florins for his servicia comunia. ASV, Cam. Ap., Intr. et Ex. 143, f. 7r (the quittance) and ASV, Cam. Ap., Oblig. et Sol. 13, f. 101r (obligation). Before his appointment to the see of Zadar, and having received only minor orders, Nicolò was general vicar to the bishop of Padua Ildebrandino Conti from Valmontone (1319-1352), an important official and diplomat at the papal court at Avignon, who administered his diocese through the household of twenty-one vicars, officials, notaries, often kinsmen or compatriots from southern Latium. The vicars who served during his long tenure were divided into two groups: those with legal knowledge and administrative skills oversaw the matters in temporalibus, the others were concerned with spiritual matters (general vicars proper). B. G. KOHL, Padua under the Carrara 1318-1405. The Johns Hopkins University Press, Baltimore and London, 1998, p. 23. A. LOMBARDI, Matafari, Nicolò in Dizionario biografico degli italiani, 72 (2009), p. 86-88.

${ }^{12}$ SMIČIKLAS, o.c., X (1912) p. 122-124 nº 80: habita quidem confessione Vulcinne Guidi de Matafarro whereas p. 131132 n 86: testibus [...] et Vulcigna condam Guidi de Matafaris.

${ }^{13}$ A document issued in Zadar in January 1337 refers to Johannes, condam Guidi de Matafaris, procurator et frater domini Demetrii de Matafaris. Id, o.c., X (1912), p. 295-296 n²25. On 7 July 1345 he was involved in the tax payment for the Benedictine friary of St. Cosmas and Damian in Rogovo: Id., o.c, XI (1913), p. 211-213 n. 162.
} 
Demetrius in Zadar ${ }^{14}$. Their brother Vučina (like his relative Peter de Matafaro in the 1320ies) was a respected advocate in the Curia civilis Jadrensis and judex examinator ${ }^{15}$ already from 1330ies, which speaks not only of his own excellent legal formation, but of other members of this noble Zaratine family as well. In the first half of 1358, when King Louis of Hungary took over Dalmatia from Venice, together with Bivaldo de Nassis and Bartholomeo de Grisogono, he was the rector of Zadar ${ }^{16}$, and again in 1359 together with Simon de Botono and Micha de Rosa ${ }^{17}$. Vučina must have died before 28 October 1366 when his widow Honesta bought a piece of land (possessionem de circa six sortibus terre) worth 500 libras from Maffeo, son of late Ivan Petrov de Matafaris ${ }^{18}$. Vučina's sons Guido and Ludovico were King Louis of Hungary's milites regii ${ }^{19}$.

From the evidence of surviving sources we can not tell much about his boyhood which he must have spent with his numerous family in the family palace close to the cathedral ${ }^{20}$, where he received basic instruction in grammar, languages and law. He was probably born before 1315 (as he did not need the papal dispensation of de defectu natalium he must have been at least thirty years old on the occasion of his bishop's appointment). The earliest source refering to him as plebanus ecclesiae Sancti Mathei ${ }^{21}$ in Zadar dates from 1336, when, probably between February and June, he was appointed subcollector decimarum sexennalium et triennalium in partibus Romaniae ${ }^{22}$ by master Bernard du Lac (de Lacu), rector of the parish church de Olonzaco, in the French diocese of Saint Pons de Tomières, archdeacon of Elne and canon of Rodez, apostolic nuncio and collector for the Apostolic Chamber of sexennal tithes imposed by the Vienne council in Lombardy and in partibus Romaniae. ${ }^{23}$ ${ }^{14}$ Id., o.c., X (1912), p. 626-628 n ${ }^{\circ} 443$ dated 26 June 1341 when the nuns domina Graçia de Betono priorissa [...], sorore
Ch [...]chia de Arbo, sorore Femia [...] Nicole de Arbo, sorore Thomasina Georgii, sorore Femia Guidi [de] Matafaris, sorore
Catharina de Ginano, sorore Benedicta de Cauatis et ceteris aliis sororibus eiusdem monasterii de consensu et uoluntate nobilis
viri Miche de Çadolinis aduocati eius monasterii consented to give for a twelve-year period loan their lands in Božava
on Dugi otok (Insula Magna) to the Zaratine citizen James, son of the late Desa de Fafogna; Id., o.c., vol. XI (1913),
p. $428-429 \mathrm{n}^{\circ} 323$ : on 27 November 1347 Gratia, priorissa, soror Thomasina de Çorço, soror Fumia de Matafaro et soror
Chatarina de Ginano, relique autem sorores, scilicet Benedicta de Çauatis, Mandiça de Çedolinis, Bonçiça de Çorgi, Franiça
de Bogde, Maria de Speglia, Çuniça Marini Petri Çani, Elena de Botono, Mariça filia Miche de Botono, Çuniça de Butadeo,
Dobriça et Nisa informed Nicholas of Ancona, vicar of the master of the Dominican order about the foundation of
St. Mary's nunnery in Nin.

${ }^{15}$ SMIČIKLAS, o.c., X (1912), p. 64-72 n 38 (Zadar, 13 January 1333); p. 122-124 n 80 (Zadar, 20 October 1333); p. 131-132 nº 86 (Zadar, 28 December 1333); p. 159-161 n. 105 (Zadar, 13 April 1334); p. 484-485 n 340 (Zadar, 15 August 1339); p. $492-494$ n 346 (Zadar, 25 September 1339); p. 506-507 n 356 (Zadar, 30 November 1339).

${ }^{16}$ SMIČIKLAS, o. c., XII (1914), p. 470-471 n. 361: Zadar, 24 April 1358.

${ }^{17}$ Id., o. c., XII (1914), p. 552-556 nº 418 (17 March 1359). The instrument bears his autograph!

${ }^{18}$ Id., , o. c., XIII (1915), p. 574-575 n 410. Bishop Demetrio and Vučina's son Guido witnessed the act.

${ }^{19}$ N. KLAIĆ - I. PETRICIOLI, Zadar u srednjem vijeku do 1409. Prošlost Zadra, knjiga II. Zadar 1976, p. 231, 334, 363.

${ }^{20}$ After having served for almost three decades in the communal government, one of the richest Zaratines, nobleman Cosa de Begna bought from Ludovico Matafari (son of his brother Vučina) his town palace close to St. Anastasia, with a shop and salt warehouse for the sum of 1000 ducats. KLAIĆ - PETRICIOLI, o.c., p. 439-440.

${ }^{21}$ The former archbishop of Zadar Ivan Butovan, Joannes Butovane, held this chuch in benefice before his episcopal election at the beginning of March 1322. Demetrio must have been provided with this benefice after 13 May1328 when it's incumbent, presbiter Johannes, is documented. SMIČIKLAS, o.c., IX (1911), p. 394-395 n. 324. In 1324 Archbishop Butovan commissioned the building of a ciborium for the St. Anastasia's Zadar cathedral. P. VEŽIĆ, Primjeri protorenesanse u Zadru in Renesansa i renesanse u umjetnosti Hrvatske. Zbornik radova sa znanstvenih skupova "Dani Cvita Fiskovića» održanih 2003. i 2004. godine. (ed. P. MARKOVIĆ - J. GUDELJ), Zagreb, 2008, p. 441-450, here 446-448.

22 J.-M. VIDAL, Benoit XII (1334-1342). Lettres closes et patentes intéressant les pays autres que la France publiées ou analysées d'aprés les registres du Vatican. Paris, 1913, col. 540-541 nº 1852.

${ }^{23}$ Id., o.c., documents dated Avignon 11 February 1336: col. 193 n 771; col. 193-194 n 772: commission to collect for the Apostolic Camera annual revenues of the prebends in the Venetian St. Mark's church; col. 194 n $^{\circ} 773$ and 774: papal letter of recommendation to the Venetian Doge and the commune. However, a few days earlier Bernard 
With his brother Nicolò at the head of the Zadar ecclesiastical hierarcy, Demetrio's ascent in the ecclesiastical career was somewhat easier. When his brother Vučina sold him a landed property in Bib$a_{n 0^{24}}$ (Bibinje) on 26 December 1342, Demetrio was already archdeacon of Zadar cathedral chapter ${ }^{25}$.

In late summer 1344 Demetrio travelled to Avignon and probably met Pope Clement VI (Pierre Roger, 19 May 1342 - 6 December 1352), as can be assumed from the supplication dated 23 September, which clearly links him with the Papacy and the curial administration. His petition for a first vacant rectorship in a Zaratine collegiate church with an annual income of thirty florins was granted by the pope himself (Fiat R.!), and the supplication was reserved a preferential burocratic procedure (indicated by the clause sine alia lectione). What happened to him in this six-year period? Here is what he wrote in the supplication:

"Supplicat Sanctitati Vestre deuotus et humilis filius uester Demetrius de Mathafaris de Jadra, archidiaconus Jadrensis, frater deuoti filii uestri Nicolay Jadrensis archiepiscopi, quod cum ipse tempore felicis recordationis domini Benedicti pape XII, predecessoris uestri fuerit missus ad partes Romanie ad colligendas decimas, sexannalem per felicis recordationis dominum Clementem papam V, et triennalem per felicis recordationis dominum Johannem papam XXII, predecessores vestros impositas, et in dicta colleccione bene et fideliter se habuerit, et propter malum haerem, qui in illis partibus erat, infirmitatem incurrerit, que ipsum viginti mensibus et vltra detinuit et fere non interemit, et post dictam colleccionem decimarum ad Romanam Curiam non fuit nec extunc a felicis recordationis domino Benedicto papa XII uel a Sanctitate Vestra aliquam graciam habuit, quatenus eidem specialem graciam facientes dignemini prouidere de primo plebanatu collegiate ecclesie non habente populum sibi astrictum et determinatum ad

received the papal plenary indulgence in articulo mortis and the licentia testandi privilege to bequeath his personal property. (col. $191 \mathrm{n}^{\circ} 762$ and 763 dated 7 February 1336). On 26 June he was authorised to exact and collect the rest of the triennal tenth imposed by John XXII (Jacques Duèze, 1316-1334) in partibus Romaniae, already levied by the prelates and collectors, but still not assigned to the Apostolic Camera (col. $251 \mathrm{n}^{\circ}$ 958). Six months later, on 31 january 1337, he was reminded again to exact and collect the money relative to both sexennalis quam triennalis decimae in partibus Romaniae, quem adhuc Camerae apostolicae assignatae non fuerunt, secundum aliud jam ipsi expressum mandatum non obstante quod praelati illarum partium personis idoneis ab eo deputatis assignare illas recusarunt (col. 344 $\left.\mathrm{n}^{\circ} 1215\right)$ and the archbishops and bishops were admonished to assign the money either to the nuncio himself or to the collectors or subcollectors he had appointed (col. $344 n^{\circ}$ 1216). In August 1334 Bernard du Lac, licentiatus in legibus apostolice sedis nuncius, and Guillelmus, decretorum doctor decanus Aquilegensis, were general vicars of Bertrand di Saint-Geniès, elected Patriarch of Aquileia. Andrea TILATTI, I protocolli di Gabriele da Cremona. Notaio della Curia Patriarcale di Aquileia $(1324-1336,1344,1350)$. Istituto Storico Italiano per il Medio Evo. Fonti per la Storia della Chiesa in Friuli Serie Medievale 1. Roma, 2006, p. 386 n $^{\circ}$ 249. dated from Udine, 28 August 1334. The death of John XXII at the end of 1334 introduced some confusion into the collection of the tenth, but in January 1335 Benedict XII (Jacques Fournier, 1334-1342), an ascetic Cisterican interested in reforming the regular Church and suppressing heterodoxy, determined to defend Church rights and revenues, confirmed the levy of the tax. However, before the end of 1336 Benedict cancelled John XXII's sexennal tenth. His faithful service shortly afterwards brought him the appointment as rector of papal Patrimony, and on 6 February 1344 he became the bishop of Viterbo. After the death on 27 July 1347 his movable property also became the object of papal right of spoil, as can be deduced by the commission to, and the account of, the treasurer of the Duchy of Spoleto Berengario Blasini. EUBEL, o. c., p. 532; WILLIMAN, The Right of Spoil ..., p. 77-78, n 163.

${ }^{24}$ A fourth part of land and a vineyard positam ad Bibanum belonged to their father Guido after 28 February 1318 , when the division was made with Damian de Stoicha. See the act registered by the Zaratine notary Nicola quondam Johannis in Spisi zadarskih bilježnika Ivana Qualisa, Nikole pok. Ivana, Gerarda iz Padove 1296-1337. M. ZJAČIĆ - J. STIPIŠIĆ, Spisi zadarskih bilježnika II. Zadar 1969, p. 165 nº 182.

${ }^{25}$ SMIČIKLAS, o.c., XI (1913), p. $28-29$ n. 21 (26 December 1342).

${ }^{26}$ A Cistercian monk Guglielmus de Curte, bishop of Alby and Pope Benedict XII's nephew, was promoted cardinal of Santi Quattro Coronati on 18 December 1338. He was appointed apostolic legate in Lombardy on 19 July 1342 (ASV, Reg. Vat. 152, f. 28r epp. 1, 2) and left the Curia on 9 October 1342. He returned from this legatine mission on 30 October 1343. He served as camerarius Sacri collegii cardinalium from 31 May 1348, and was translated to the see of Tusculum on 18 December 1350. He died on 12 June 1361. EUBEL, o.c., p. 17. 
curam animarum vacante uel vacaturo in ciuitate Jadrensi, eciam si in eodem plebanatu per eleccionem assumatur et in ecclesia collegiata dignitas fuerit principalis, cuius annui redditus secundum taxationem decime summam triginta florenorum auri non excedant. Cum nullus auctoritate Sanctitatis Vestre in dicta ciuitate sit expectans, non obstante quod archidiaconatum Jadrensem et capellas Sanctorum Thome de Jadra et Grisogoni Jadrensis diocesis et quandam decimam Rogoue et villarum eius dicte diocesis obtineat et auctoritate domini Guilelmi, tituli Sanctorum Quatuor Coronatorum presbiteri cardinalis ${ }^{26}$, olim in dictis partibus apostolice sedis legati, sit canonicus Sibinicensis et in possessione ipsius canonicatus et prebende missus, licet idem canonicatus et prebenda eidem detineantur, quorum archidiaconatus, beneficiorum et decime annui redditus secundum taxacionem decime summam quinquaginta florenorum auri non excedunt. Cum accepcione, reseruacione, inhibicione, decreto et clausula anteferri. Et cum ceteris non obstantibus et clausulis opportunis et execucione. Fiat $R$. Et quod transeat sine alia lectione. Fiat $R$. Datum apud Villamnouam Auinionensis diocesis nono Kalendas Octobris anno tercio. ${ }^{27}$

We learn that the position of archdeacon in Zadar cathedral chapter as well as the rectorship of two Zaratine chappels, St. Thomas and St. Chrysogonus, ensured him an annual revenue of fifty florins, and was still involved in the levies of the Rogovo abbey tithes. In his search to defend himself from the acuses for not fullfilling his duties towards the apostolic nuncio and collector Bernard du Lac, and to back up his petition, he resorted to the classical excuse: due to bad climate in his collectoria he got seriously ill and was confined to bed for more than twenty months that he almost died! How difficult was the economic situation in Zadar in the 1330ies - when Demetrio acted as subcollector, can be deduced from the authorisation of Pope Benedict XII given to archbishop Nicolò Matafari on 22 June 1337, to absolve the nuns of St. Nicholas from the interdict cast upon them by Bertrando Rotundi, collector decimarum in partibus ipsis. ${ }^{28}$

However, while he was still in Avignon, on 23 February 1345 the Pope provided him to the see of Pedena $^{29}$ (Pićanj, Petinensis diocesis) in Istria, suffragan to the see of Aquileia ${ }^{30}$, which lay vacant for many years ${ }^{31}$, and for perhaps a year after the death of the last bishop, Dominican friar and apostolic

${ }^{27}$ ASV, Reg. Suppl. 7, f. 12v; this is a revised transcription of the supplication published by SMIČIKLAS, o.c., XI (1913), p. $157-158$ n $^{\circ} 117$.

${ }^{28}$ Id., o.c., X (1912), p. 328-329 n² 251.

${ }^{29}$ ASV, Reg. Vat. 163, ff. 76v-77r. Hierarchia catholica medii aevi sive summorum pontificum, S.R.E. cardinalium, ecclesiarum antistitum series ab anno 1198 usque ad annum 1431 perducta e documentis tabularii praesertim Vaticani collecta, digesta, edita per Conradum EUBEL. Monasterii 1913, p. 397.

${ }^{30}$ Pope John XXII reserved to himself and the apostolic see «for so long as it should please them and by virtue of plenitudo potestatis, the provision of all patriarchal, archiepiscopal, episcopal and other churches in the Patriarchate of Aquileia and in the provinces of Milan, Genua and Pisa with the constitution In apostolicae sollicitudinis specula published on 30 July 1322. G. SILANO, Episcopal elections and the Apostolic See. The Case of Aquileia: 1251-1420 in Diritto e potere nella storia europea. Atti in onore di Bruno Paradisi. Quarto Congresso Internazionale della Società italiana di storia del diritto. Firenze, 1982, vol. 1, p. 163-194, here 176.

${ }^{31}$ The apostolic collector who collected the tithes in Istria in 1333 could observe: Item de civitate et diocesi Petenense nichil fuit exactum propter absentiam episcopi nec erat ibi aliquis clericus qui sciret huiusmodi officium exercere et sunt beneficia quam modici valoris. in: Rationes Decimarum Italiae nei Secoli XIII e XIV. Venetiae - Histria - Dalmatia. a c. di P. SELLA - G. VALLE. Studi e testi 96. Città del Vaticano, Biblioteca Apostolica Vaticana, 1941, p. 347: Pedena, Residui di decime degli anni 1333. (Arch. Vat., Collect. 200, f. 128v, e 137: 3420: f. 137v). At the provincial council held in Aquileia between 25 and 27 April 1339 convened by the Patriarch Betrando de Saint Geniès in the presence of nine suffragan bishops (Ildebrando Conti of Padua, Gorizia, Feltre and Belluno, Benedetto of Como, Guido of Concordia, Blasio of Vicenza, Pietro Paolo of Treviso, Natale of Emona, Giovanni of Poreč, and Marco of Kopar, and proctors (Ermanno of Parma to represent Niccolò bishop of Trento, friar Filippo to represent Pace bishop of Triest, priest Menero to represent Sergio bishop of Pula, Francesco di Bologna to represent Francesco Ramponi bishop of Ceneda) the bishopric of Pedena was vacant, administered by the cathedral chapter, but for the occasion was represented by the economo, Guglielmo, provost of Pazin. However, on 31 July 1343 a clerk of the Apostolic Chamber issued the quittance 
minor penitentiary Stanislao de Cracovia ${ }^{32}$. By the mid fourteenth century the practice of bishop's election by the cathedral chapters (when archdeacons and suffragan bishops could claim a right to elect) was seriously affected by the extensive use of papal right to provide, much more marked in the case of bishoprics than any other ecclesiastical benefice or office. Yet, it is hard to believe that the ecclesiastical elites had lost interest in the identities of their colleagues who would become their bishops. It therefore seems likely that there were numerous informal interventions, but now the pope was only suggested whom he might appoint, while his administration proceeded to levy service taxes in return for the issuing bull of provision. So, before receiving the bull of provision for his new episcopal dignity in Pedena, Demetrio had been required to pay, or to promise to pay, the fees owing to the Curia by himself and by his predecessors, who had died too quickly and had not paid all they owed. In fact, on 25 May 1345 in Avignon, Demetrio promised to pay the sum of one hundred florins for the common services fee $\mathrm{e}^{33}$, and an additional sum for the five servicia consueta due to the Apostolic Camera, and agree to pay his due in two periods, the first one on Easter, the second on St. Michael's feast (29 September). On the Secret Consistory which provided him bishop of Pedena, twenty-six cardinals were present ${ }^{34}$. Then, he had to be examined for the suitability if this was not already clear. He might have been examined in the Curia by a panel of three cardinals, or the pope delegated three local bishops who also had authority to confirm the election. Probably, there were fewer investigations into the quality of bishops-elect now than formerly, since most candidates were well known to the pope himself or the curial officials from earlier contacts or supplications. They were university graduates or secular clerics who, before the consecration already held a number of benefices or prebends in cathedral or collegiate churches, often using papal favour to advance on the hierarchical ladder. Finally, the consecration ceremony followed. Among the peculiar competences of the Patriarch of Aquileia was the right to confirm the elections of the suffragan bishops in his province and to consecrate them. Therefore, in the next few months following his appointment, Demetrio Matafari must have been consecrated by Bertrando di Saint-Geniès himself! His bishop's consecration by the Patriarch could have happened at the very beginning of 1346, when his presence in Udine is indirectly confirmed. Namely, on the feast of Conversion of St. Paul, 25 January 1346, two friars Achiloto and Anzuto of the Dominican convent of San Pietro Martire in Udine, declared to the notary that they have received in deposito from the Patriarch some books belonging to "the bishop of Pedena ${ }^{35}$. Only a few years earlier, on 23 November 1342, the Patriarch, too, donated a collection of his books, to be used for the formation and instruction of the cathedral's younger chaplains, to the St. Mary's Chapter in Udine ${ }^{36}$. The short list of books sheds light on the early fourteenth century curial prelate's library, on the books he bought, read, or considered of utmost importance in the formation of clergy in general and of a bishop in particular. His library contained a copy of Flores sanctorum, identified by C. Scalon as Legenda aurea of the Domenican bishop Iacopo da Voragine. Like his metropolitan superior, Demetrio Matafari also had a copy of Flores sanctorum ${ }^{37}$. The two prelates'

to the bishop of Pedena Stanislao relative to the payment of 50 florins for the common service tax of his predecessor Amantius. ASV, Cam. Ap., Intr. et Exit. 208, f. 12v; 209, f. 17v; 214, f. 6v; 215, f. 11r; 219, f. 6r; 220, f. 15v. G. BRUNETTIN, Bertrando di Saint-Geniès patriarca di Aquileia (1334-1350). Presentazione di Paolo Cammarosano. Istituzioni e società 6. Spoleto, Fondazione Centro italiano di studi sull'alto medioevo, 2004., p. 421, note 71, 72, p. 636.

${ }_{32}$ ASV, Reg. Vat. 147, ff. 64v-65r: Avignon, 21 April 1343, promise to pay the common services registered in: ASV, Cam. Ap., Oblig. et Sol. 6, f. 203r dated 22 April 1343.

${ }^{33}$ This service tax (servitia) was payable by those appointed by the pope to major benefices (archbishops, bishops, abbots). Its main constituent, common services, amounted to a third of the benefices' gross annual income.

${ }^{34}$ ASV, Cam. Ap., Oblig. et Sol. 14, f. 100r; and 16, f. 108v.

${ }^{35}$ Atti della Cancelleria dei patriarchi di Aquileia (1265-1420). (a c. di) I. ZENAROLA PASTORE. Pubblicazioni della Deputazione di Storia Patria per il Friuli 12, Udine 1983, p. 168.

${ }^{36}$ BRUNETTIN, o.c., p. 642.

${ }^{37}$ C. SCALON, Produzione e fruizione del libro nel Basso Medioevo. Il caso Friuli, Padova 1995, p. 174-175 n 75; p. 181$182 n^{\circ} 83$. 
book collections deposited in the Chapter and the Dominican convent of Udine, was a step towards making the books of thelogical, legal or ecclesiastical culture accessible.

Demetrio's new diocese was not a rich one. Like all bishops provided or confirmed by the Pope on the Secret consistory, he promised to pay his servitia communia, common services fee, which was extimated at one third of the total annual income. If he promised to pay one hundred florins, it means that the annual income did not exceed 300 florins. Although he had promised to pay the first half of his services by Easter 1346, he asked for, and was accorded, a postponement of his payment. So, on 18 December 1347 he was able to pay only 50 florins for the common services, and 7 florins, 16 solidos and 8 denarios of Avignon money to the clerics of the Camera through his proctor, the Florentine merchant Francesco Venuctii de Senis ${ }^{38}$. Regretfully, the debts owed to the Apostolic Camera / Holy See were to constitute a perennial problem for Demetrio!

During the difficult period of the Hungarian-Venetian war for Zadar, which began with the Zaratine insurrection on 12 August 1345 and ended with a disastrous defeat on 21 December 1346, Demetrius was probably travelling from Avignon to the see of his metropolitan superior to be consecrated and confirmed in his dignity and to take possession of his diocese. On the other hand, his brother Nicolò, archbishop of Zadar, preferred to leave his hometown, and spent the next years between Padua ${ }^{39}$ and Udine/Aquileia protected by his friends - bishop Ildebrandino Conti (1319-1352) ${ }^{40}$ and the Patriarch of Aquileia, fellow-countryman of Pope John XXII, Bertrando di Saint-Geniès, who took possession of the Patriarchate on 28 October 133441. A series of papal privileges reveal that at the very beginning of 1346

\footnotetext{
${ }^{38}$ ASV, Cam. Ap., Oblig. et Sol. 21, f. 86v and the relative quittance in Cam. Ap., Intr. et Exit., 250, f. 14v.

${ }^{39}$ At Venice's request the lord of Padua, Giacomo II Carrara sent a contingent of Paduan troops to the defence of Zadar under siege by Louis of Hungary during the autumn 1345, and on 6 December a Venetian envoy in Padua agreed to pay the amount owed for their services. Throughout 1346 he continued his aid of Venice in its struggle to retake Zadar. In May he dispatched a force of two hundred horsemen and one hundred crossbowmen for the renewed fighting in Zara, and in recognition of this, he was summoned to Venice to participate in the festivities marking the successful end of the war. B. G. KOHL, Padua under the Carrara, 1318-1405. The Johns Hopkins University Press, Baltimore and London, 1998, p. 90-91.

${ }^{40}$ Before and after his election to the see of Padua in 1319, Ildebrandino from Valmontone del Lazio travelled troughout Europe (from Catalonia to Hungary and Germany, from Genoa to Naples) in diplomatic missions for the Papal curia. He was a man of culture, a jurist who read works of Seneca and St. Augustin. Out of twenty-one vicars general in his service, only three were from Padua. P. SAMBIN, La familia di un vescovo italiano del '300 in Rivista di storia della Chiesa in Italia 4/2 (1950), p. 237-247, here 237, 241; B. G. KOHL, Conti, Ildebrandino in Dizionario biografico degli italiani 28 (1983), p. 438-440. Nicolò was in Padua in June 1354 when he was requested by Innocent VI to collect the necessary information on Mariotta, daughter of Bongiovanni of Padua, nun at the Benedictine nunnery of Blessed Mary de Ispia, elected abbess of the same nunnery following the death of the late abbess Beatrix, and to dispense her from the defect of birth, as she was born out of a relationship of two unmarried persons. THEINER, o. c., p. 231-232, nº 311 (8 June 1354).
}

For some time Nicolò Matafari was vicar general to the bishop of Padua Giovanni Orsini (!!), as can be deduced from the document registered on 19 February 1355 by the ordinary judge and notary, officer of the episcopal curia of Padua, Nicholas, son of master Bartolomeo, inhabitant in the centenario of St. Thomas, quarterio et contrata Domi, relative to the archbishop's sentence regarding the collation of the church of St. Martin de Plano in Monselice, in favour of the monastery of Santa Giustina and its prior. In: Il catastico verde del monastero di S. Giustina di Padova. A c. di L. CASAZZA. Saggi introduttivi di L. CASAZZA - F. G. B. TROLESE. Fonti per la storia della Terraferma Veneta 24. Roma, Viella, 2008. p. 360-363 n 182, 183.

${ }^{41}$ Bertrando was already old when he was elected patriarch of Aquileia. He was a doctor of both laws, and at least until 1314, taught law at the University of Toulouse. He became papal chaplain, auditor of causes in the papal palace, a diplomat, strong and firm man of politics, a fervent supporter of Aquileian protomartyrs St. Hermagoras and Fortunato cults, and a generous patron of arts. L. CRUSVAR, Il tesoro della basilica patriarcale in Patriarchi. Quindici secoli di civiltà fra l'Adriatico e l'Europa Centrale. (a c. di: S. TAVANO e G. BERGAMINI), Mostra 3 luglio - 10 dicembre 2000. Milano, Skira, 2000, p. 177-191, here 180, 188. The presence of Ildebrandino de Conti in Padua, of Bertrando de Saint-Geniès in Aquileia and Guido de Guisis in Concordia seem to be a part of an ambitious political and spiritual design of Pope John XXII, who formed his diplomatic and administrative experience in the labyrinth of the Anjou 
the Patriarch was engaged by Pope Clement VI (Pierre Roger,1342-1352) in a diplomatic mission at the court of Louis of Hungary. The formal papal letter to appoint him and Francesco d'Amelia, bishop of Triest, apostolic legates with the faculty to convene a proper national ecclesiastical council, was issued on 9 January ${ }^{42}$. The Patriarch probably set to journey in March 1346 with the first signs of thaw, and was present at the court in July when the King ordered the military action against the Venetian army besieging Zadar. Moreover, the Patriarch's chancery followed an ordinary procedure which did not need the Patriarch's endorsement. Thus, the period early March - late August can be identified as the period of the Patriarch's absence. He secretly sustained the King's expansionistic project of the dinastic reunion, as the conquest of Dalmatia would have swept away or at least diminished the Venetian monopoly in the northern Adriatic regions, and the claims upon the ecclesiastic principality of Aquileia ${ }^{43}$.

Anyway, two brothers, the archbishop of Zadar in exile and the bishop of Pedena, will be engaged for the consecration ceremony of the new bishop of Concordia Constantino, son of Federico Savorgnan, canon of the cathedral chapter and provost of St. Stephen of Aquileia, Patriarch's close parent and confident, provided by Pope Clement VI at the end of 1347, in the church of St. Mary Major in $U_{d i n e}{ }^{44}$ on 6 April 1348. The solemn ceremony was officiated by the Patriarch himself in the presence of the archbishop of Zadar Nicolò Matafari, and the bishops of Melfi Pierre di Cluzel ${ }^{45}$ (1347-1348) and Pedena (Pićanj) Demetrio ${ }^{46}$. Savorgnan succeded the patriarch's general vicar, a very close collaborator and a reliable friend, fine jurist and canonist, professor in Bologna from 1313 to 1316, bishop of Modena Guido de Guiçis/Guisis (16 September 1334 - spring 1347, buried in the St. Francis church at Udine).

Several months earlier, on 21 March 1347, Demetrio carried out a pastoral visitation of Mortegliano. Thanks to his personal qualities and his canonistic expertise, he became another figure included into the group of the Patriarch's vicarii in spiritualibus ${ }^{47}$.

chancery, to reform the temporal privileges of the Church in Italy, starting from the reasonable but firm defence of ecclesiastical rights and privileges, which only these three capable and true collaborators, prelates and jurists could implement. BRUNETTIN, o.c., p. 846.

${ }^{42}$ ASV, Reg. Vat. 139, f. 305v, ep. 1342; ff. 183r-185r, ep. 780, ff. 282v-285r.

${ }^{43}$ BRUNETTIN, o. c., p. 648-649, 671-685.

${ }^{44}$ The Patriarch undoubtedly felt at ease in Udine, a stronghold of his jurisdiction. Here, the canons of the Aquileia cathedral chapter, with whom the confidential relations have still not been established, could not obstruct his reform efforts. In St. Mary de Castello church at Udine he convened his first magnificent provincial council on 29 May 1335, as the supreme expression of power and metropolitic authority. This was a formidable act of political propaganda addressed to the citizens of Udine who ensured their financial support. On the other hand, it was the first official contact with his suffragan bishops, who reunited in Udine to discuss and define the metropolitic governance and the political situation in the province. BRUNETTIN, o. c., p. 403, note 15.

${ }^{45}$ Regretfully, Costantino Savorgan died on 7 May 1348 and Bertrando had to act quickly and decidedly at the Apostolic Curia: already on 30 May Pope Clement VI translated the Dominican friar and bishop of Melfi Petrus de Clausel to the see of Concordia. Pierre's family was closely related to the family of cardinal Gaucelm de Jean, nephew of Pope John XXII, and to the Saint-Geniès. Bertrando must have made his acquaintance in the studia of the Dominican province of Toulouse. (BRUNETTIN, o.c., p. 806). Already on 20 January 1345 Bertrando had to appoint a vicarius in pontificalibus - his choice was Dominican friar Giovanni Gottoli de Sordelli of Bologna to assist Guido de Guisis in his office of patriarchal provincial tribunal. After Guido's death he chose Nicolò Matafari as his vicar general. It is significant that the vicars who took over Guido's positions belonged to the group of Dominican bishops of the province itself or the neighbouring dioceses, and who had a degree in canon law (decretorum doctor). Nicolò prefered the Patriarch's hospitality during the disasterous insurrection of his hometown Zadar. During his stay in Aquileia in the years 1346-1351, he wrote his major work Thesaurus pontificum seu manuale personarum ecclesiasticarum Nicolai archiepiscopi Jadrenis dedicated to Bertrand du Pouget, cardinal of Ostia and Velletri. P. JUGIE, Un Quercynois à la cour pontificale d'Avignon: le cardinal Bertrand du Pouget (v. 1280 - 1352), in La papautè d'Avignon et le Languedoc 1316-1342, Cahiers de Fanjeaux. Collection d'Histoire religieuse du Languedoc aux XIII et XIVe siècles 26. Toulouse 1991, p. 69-95, here 83, 86, 95.

${ }^{46}$ ASV, Instr. Misc. 1757; L. GIANNI, Un caso di fedeltà compromessa: il vescovo Pierre di Cluzel (1348-1360) e il suo legame con la cattedra Aquileiese, in Atti dell'Accademia "San Marco", 12 (2011) p. 9-86, here 11.

${ }^{47}$ BRUNETTIN, o.c., p. 815. "Demetrio compi la visita nella pieve e vi riscontrò odio tra gli uomini abitanti e l'esistenza di una faida con morti; allora provvide alla pacificazione delle genti della pieve, con un patto di perpetuo 
An interesting document dated 21 May $1350^{48}$ refers to his affairs in Zadar connected to the Apostolic Camera. Namely, somewhat earlier from Venice with his autograph letter sealed with his own seal, he authorised his proctors - the archdeacon of Zadar cathedral Chrysogonus and the rector of St. Mary the Major George, now vicar of archbishop Nicolò, to annull the judicial case he had moved years before against the abbess and the nuns of St. Nicholas abbey, relative to the provision for the apostolic legate Gui de Boulogne, cardinal priest of Santa Cecilia ${ }^{49}$. Two years later, on 19 October 1352, personally present before the count of Pag on the city main square (logia!), he had to defend himself and his family from the false accusation of the Venetian count and captain of Zadar Giustiniani, for disobeying the prohibition to export grain from the island of Olib to Pag ${ }^{50}$. Although away from their hometown, and notorius supporters of King Louis of Hungary's politics, the Matafari brothers were considered dangerous by the Venetian administration in Zadar!

As a suffragan bishop of the Patriarch of Aquileia, Demetrio must have assisted the solemn funeral ceremony for Bertoldo de Saint-Geniès, killed on 6 June $1350^{51}$ : in Utino in ecclesia maiori honorifice per Utinenses fuit sepultus et postea multa miracula fecit et quotidie facit, ut apparet in Libro Miraculorum suorum qui est in Utini in ecclesia maiori ${ }^{52}$.

On 21 February 1354 Innocent VI (Stéphane Aubert, 1352-1362), post deliberationem diligentem quam cum fratribus nostris habuimus, consideratis grandium virtutum tuarum meritis, quibus personam tuam latissimus insignivit, absolved Demetrio from the ties he had with his diocese and transferred him to Nin,

accordo sotto pena di cento marche aquileiesi, emettendo la sentenza contro i colpevoli che prevedeva l'espiazione con la costruzione di un altare dedicato al Santissimo Sacramento, in suffragio delle anime degli uccisi, a spese di entrambe le parti. La pacificazione venne ratificata apponendo alla fine dell'atto il giuramento solenne a rispettare la pace espresso da ciascuno dei componenti delle due fazioni. Si tratta di un esempio della portata anche sociale dell'azione del vicario e quindi delle visite pastorali, a indicare la stretta correlazione tra l'ambito della giurisdizione spirituale e quello della giurisdizione civile.»

${ }^{48}$ SMIČIKLAS, o. c., XI (1913), p. 602-604 n 460.

${ }^{49}$ Archbishop of Lyon Gui de Boulogne was created cardinal priest of Santa Cecilia during the first cardinal promotion of Clement VI on 20 September 1342. In early 1349 the Pope tried to establish a general truce in order to promote the free passage of pilgrims to Rome for the Jubilee, and cardinal Gui de Boulogne was one of the key figures in this effort. On his way to Germany and Hungary to promote papal policy, he visited the Carrara court at Padua. The cardinal legate returned to Padua twice during the next few months. First, for the translation of San Antonio's body to a new tomb in February 1350, and, second, to preside over a synod of clergy from the cities of northern Italy to bring peace to the area and define the jurisdiction of the patriarch of Aquileia and the count of Gorizia that April. On both occasions the cardinal might have met the two Matafari brothers. After his return to the Curia on 7 June, he was promoted cardinal bishop of Porto. KOHL, o.c., p. 94. He died on 25 November 1373. EUBEL, o.c., p. 18. ${ }^{50}$ SMIČIKLAS, o.c., XII (1914) p. 129-130 n. 89.

${ }^{51}$ «Nella sagrestia del duomo di Udine, in attesa di essere collocati nel Museo dell'Opera del Duomo, si conservano tre dipinti su tavola raffiguranti il beato Bertrando [...] celebre professore di diritto all'Università di Tolosa e cappellano di papa Giovanni XXII che da Avignone lo promosse alla sede aquileise, [che] favorì l'istituzione di un'università a Cividale nel 1344, trasferì la sede patriarcale a Udine, nel 1348, difese e rivendicò i diritti del patriarcato contro i duchi d'Austria, i conti di Gorizia e i nobili friulani. Questi ultimi congiurarono contro di lui e nel 1350 lo uccisero, novantenne, presso San Giorgio della Richinvelda, a tre miglia da Spilimbergo, mentre ritornava a cavallo, con il suo seguito da Sacile a Udine. Nel duomo di Udine si conservano il suo sarcofaco (che egli stesso aveva fatto costruire per custodire le spoglie dei protomartiri Ermacora e Fortunato ma che divenne la sua tomba), opera insigne di scultura che si ritiene eseguita su disegno di Andriolo de Santi, e un consistente numero di oggetti del suo corredo personale o da lui posseduti. G. BERGAMINI, La Carità del Beato Bertrando; L'Uccisione di Bertrando in Patriarchi. Quindici secoli di civiltà fra l'Adriatico e l'Europa Centrale. Catalogo della mostra 3 luglio - 10 dicembre 2000. S. TAVANO, G. BERGAMINI (a c. di), Milano, Skira, 2000. p. 218-220, here 218.

${ }^{52}$ BRUNETTIN, p. 829, 838: «Successivamente, secondo l'agiografo, il corpo viene accolto dal ceto clericale, formato dal clero della collegiata che lui stesso aveva costituito e dai religiosi degli ordini mendicanti che nella città avevano ottenuto spesso manifestazioni della sua benevolenza», and "Nella chiesa maggiore, che splendeva delle opere dell'arte insigne di Vitale da Bologna che Bertrando aveva voluto farvi eseguire a spese della mensa patriarcale, egli stesso avea stabilito le modalità di seppellimento e del suffragio della sua anima...». 
which had been reserved to the papal provision, and was vacant following the death of the late bishop Johannes $^{53}$. Similar letters to inform them of the translation were sent to the canons of the cathedral chapter, to the clergy and populace of Nin as well as to the archbishop of Split, his metropolitan who would receive his fidelity oath ${ }^{54}$. On 5 April 1354 camerarii of the Apostolic Chamber commissioned to the bishops of Rab and Krk, or to their vicars, to inform the Curia about the exact value of the church of Nin to which Demetrio had recently been transferred. Together with the papal letter of provision the commission was given to Demetrio, and he promised to present the letter to the commissioners ${ }^{55}$. On 29 May 1355 a document reached the Apostolic Chamber officials in Avignon, written and signed by master Christopher de Zambonio de Rodano, notary by imperial authority, with Demetrio's promise to pay his common service fees through his proctor, Christopher de Cadinico from the diocese of Rab ${ }^{56}$. From this period of his ecclesiastical career numerous documents refer to him present in Zadar and taking care of his family affairs, or acting on behalf of his brother, the Archbishop. In a document issued from the archbishop's palace court on 28 December 1357 he is referred to as vicar of the archbishop of Zadar. On that occasion he received the petition of Ricardo, monk and vicar of St. Chrysogonus, who, in the absence of his abbot requested that the payment of triennal tenths due to the apostolic legate Egidio Albornoz, cardinal of Santa Sabina, be postponed ${ }^{57}$. Numerous royal charters refer to him as the bishop of Nin, when his presence as a distinguished witness was registered ${ }^{58}$. The last time we will find both brothers witnesses of royal charters is the document issued on 8 February $1367^{59}$.

Difficult times for the family arrived somewhat before the end of October 1366 when Vučina died, and was followed by the death of Nicolò just before 18 March 136760. On 1 September 1367

\footnotetext{
${ }^{53}$ According to C. F. Bianchi, Johannes IV also belonged to the Matafari family. On the provincial synod convened in 1344 at Split by the archbishop Domenico Luccari, he was represented by the archpriest Stanzio. C. F. BIANCHI, Zara christiana, II, Zara, 1879, p. 211-212.
}

${ }^{54}$ ASV, Reg. Vat. 225, f. 34r-v, ep. 20; THEINER, o. c., p. 231-232 n 309; SMIČIKLAS, o. c, XII (1914), p. 227-228 nº 170; P. KANDLER, Codice Diplomatico Istriano, Trieste, Editore Tipografia Riva S.p.A., III, $1986^{2}$, p. 1259, n 744. His successor in Pedena Nicolò was appointed on 28 March (ASV, Reg. Vat. 225, f. 35r-v, ep. 22; THEINER, o. c., 231, n 310; KANDLER, o. c., p. 1260-1262, n 745. Bishop Nicolò promised to pay the common service fee on 5 April 1354 in Avignon (Cam. Ap., Oblig. et Sol. 22, f. 155v) and on 6 April 1356 (Cam. Ap. Oblig. et Sol. 30, f. 120r), and the subsequent quittances were issued on 10 January 1355 and on 6 April 1356: (ASV, Cam. Ap., Intr. et Exit. 262, f. $37 \mathrm{r}$; and $275 \mathrm{f}$. 10v when his proctor Bartoleto de Pisis paid the sum of 50 florins; see: H. HOBERG, Die Einnahmen der Apostolischen Kammer unter Innozenz VI. Zweiter Teil: Die Servitienquittungen des Päpstlichen Kamerars. Vatikanische Quellen zur Geschichte der Päpstl. Hof- und Finanzverwaltung 1316-1378. Paderborn - Wien 1972, p. 162.

${ }^{55}$ ASV, Cam. Ap., Oblig. et Sol. 28, f. 193v.

${ }^{56}$ ASV, Cam. Ap., Oblig. et Sol. 22, f. 173r.

${ }^{57}$ SMIČIKLAS, o. c., XII (1914), p. 440 n 337. Archbishop of Toledo Egidio Alvari Albornoz was created cardinal of St. Clement by Pope Clement VI during his fourth cardinal promotion on 17 December 1350. On 13 August 1353 he was sent for the apostolic legation in Lombardy and in December 1356 arrived the promotion to cardinal bishop of Sabina. He died in Viterbo on 23 August 1367. EUBEL, o. c., p. 18.

${ }^{58}$ SMIČIKLAS, o.c., XII (1914), p. 504-505 n 338 (23 August 1358); p. 552-556, no 418 (17 March 1359); p. 556-558 nº 419 (19 March 1359); p. 565-566 n 427 (25 April 1359); p. 568-569 n 429 (30 April 1359), p. 603-605 n 453 (15 August 1359); p. 612-613 n 461 (30 August 1359); p. 621-622 n 470 (6 September 1359); p. 624-626 n 473 (27 September 1359). ${ }^{59}$ Id., o. c., XIV (1916), p. 4-5 nº 4.

${ }^{60}$ The notary and chancellor of Zadar, cleric Bronich Francisci de Firmo issued a document on 18 March 1367 which probably reveals his embarassment with the news of the archbishop's death. This is how he dated the document: [...] anno ab incarnatione eiusdem millesimo trecentesimo sexagesimo septimo, indictione quinta, die decimo octauo mensis marcii [...] domino (!) archiepiscopo (!) Jadre propter eius mortem vacante. SMIČIKLAS, o. c., XIII (1916), pp. 11-12, n. 7. The see of Zadar remained vacant for more than a year. His successor, Dominican friar Dominico was translated from the bishopric of Ston-Korčula and on 15 June 1368 paid the sum of 126 florins as a part of his common service fees to the Apostolic Camera through his proctor Mathew Symonis, canon of the Zagreb cathedral. ASV, Cam. Ap., Intr. et Exit. 325, f. 15r. Camera Apostolica. Annatae, Introitus et exitus, obligationes pro communibus servitiis, obligationes et solutiones - Additamenta. (1302-1732). Svezak 2. Priredili J. BARBARIĆ et al. Zagreb-Rim, 2001, p. 343 n 581. 
Demetrius was in Viterbo where the Curia of pope Urban V (Guillaume de Grimoard, 1362-1370) resided. He must have arrived there somewhat earlier, just in time to assist the funeral ceremony of cardinal Egidio Albornoz who died in Viterbo on 23 August. However, on 1 September he visited the pope's camerarius Arnaldo in his office in the Apostolic Camera and paid 6 florins for himself and his cathedral chapter, relative to the triennal tithe imposed by Innocent VI and Urban V on ecclesiastical persons of his city and diocese, which was confirmed by a quittance ${ }^{61}$. Moreover, he had to settle a much greater debt with the Camera, but was unsuccessful! The surviving documents do not tell much about what had happened between the two. Demetrio must have left the Curia in great secret very soon, as can be deduced from the letter sent on 20 January 1368 by the chamberlain to the Doge and officials of the Veneto asking their help in capturing the fugitive bishop from arrest in Rome ${ }^{62}$. Then, on 31 January Urban V sent a letter to the communes of Zadar and Nin announcing the appointment of Bertrand Ebrard, bachellor in canon law, and his imminent arrival ad partes Sclavonie to settle certain affairs for the Apostolic Camera ${ }^{63}$. Similar papal letter was also sent to the Doge in Venice, asking him to assist Bertrand in promovendis eisdem negociis nostris et apostolice sedis ${ }^{64}$. Only on 10 June 1368 from Montefiascone in a letter addressed to Bertrand Ebrard Urban V refered to the even: [...] Cum Demetrius Episcopus Nonensis ex certis causis in magnis pecuniarum quantitatibus apostolice Camere teneatur, pro quibus olim existens in romana Curia cum gentibus Camere nostre componere voluit pro summa decem milium florenorum seu ducatorum auri; sed postmodum nostra licencia non obtenta, de ipsa Curia clam recessit, et profugus vadit hinc inde, sua Nonensis derelicta [...], and authorised him to: [...] nomine nostro et dicte camere petendi, exigendi ac recipiendi, et ad manum tuam ponendi quecumque bona mobilia et immobilia, ac credita eiusdem Episcopi, ubicumque et apud quoscumque consistant, eaque vendendi et alienandi et precii recipiendi usque ad summam sexdecim milium florenorum auri, et insuper, cum ipso Episcopo, vel eius procuratore ad hoc ab eo mandatum habente de hiis, in quibus tenetur prefate Camere, pro summa, de qua tibi videbitur, dummodo saltem ascendat ad summam decem milium florenorum auri, componendi, et quoscumque solventes de receptis quitandi, et alia faciendi, que in hiis fuerint oportuna $[. . .]^{65}$. Bertrand must have set to journey almost immediately and spent the summer in Zadar and Nin, where he met the authorities, collected Demetrio's movable property and redacted the inventory. By 9 December of the same year he returned to Rome, delivered the books, jewels, utensils, chalices, patenas, vestments and clothing to Giovanni Rossetti, and the chamberlain Arnoldo issued a receipt ${ }^{66}$. This is what was confiscated:

Vniuersis et singulis presentes litteras inspecturis. Arnaldus miseratione diuina archiepiscopus Auxitanus, domini pape camerarius. Salutem in domino. Vniuersitati vestre tenore presencium innotescat quod venerabilis vir dominus Bertrandus Ebrardi, rector parrochialis ecclesie de Lumberiis Albiensis diocesis, commissarius ad recipiendum apostolice Camere nomine omnia et singula quecunque bona domini Demetrii episcopi Nonensis, ex certis causis prefate Camere obligata auctoritate apostolica specialiter deputatus,

\footnotetext{
${ }^{61}$ ASV, Instr. Misc. 2471, rotulus 4; ASV, Cam. Ap., Intr. et Exit. 323, f. 10r. "[m.s.] de decimis. Die prima mensis Septembris recepti fuerunt in Viterbio domino nostro papa tunc ibidem residente a domino Demetrio episcopo Nonensi, in prouincia Spalatensis, in Dalmassia, in Regno Vngarie, racione decime triennalis dudum per felicis recordationis Innocencium pape VI. et istum dominum Vrbanum papam V. super personis ecclesiasticis suarum ciuitatis et diocesis Nonensis imposito < de pecuniis per ipsum ibidem receptis pro dicta decima ad cameram apostolicam pertinentibus > ipso domino episcopo manualiter soluente pro se et capitulo dicte sue ecclesie Nonensis ac eius clero pro vno triennio dicti quondam domini Innocencii pape VI. et pro vno alio triennio istius domini nostri pape Vrbani quinti pro quolibet <anno dictorum trienniorum $>$ VI. flor(enos) ascendunt in summa et fuit eidem episcopo concessum quod si reperiretur ipsum soluisse tempore dicti quondam domini Innocencii pro dicta decima ultra summam per ipsum occasione dicte decime <debitam $>$ quod Camera apostolica ad illud plus eidem domino episcopo soluere teneatur et e contra. XXXVI florenorum de Camera.

${ }^{62}$ ASV, Cam. Ap., Collect. 353, f. $97 \mathrm{v}$.

${ }^{63}$ THEINER, o. c., p. 259 n 357.

${ }^{64}$ Id., o. c., p. $260 \mathrm{n}^{\circ} 358$.

${ }^{65}$ Id., o. c., p. 260 n 359. SMIČIKLAS, o.c., XIV (1916), p. 140-141, nº 91.

${ }^{66}$ ASV, Cam. Ap., Collect. 353. ff. 133v-134v.
} 
die datum presencium de bonis huiusmodi per eum, vigore commissionis apostolice super eo sibi facte, receptis, nobis presentibus, Camere supradicte realiter assignauit que sequitur: Et primo Inforciatum ${ }^{67}$ qui secundo suo folio incipit "Insolidum» et finit in penultimo folio "annualis" sic extimatum ad vnum florenum auri, item Digestum nouum quod incipit in secundo sui folio in textu eciam "fabris", extimatum ad vnum florenum auri. Item vnum codicem qui incipit in secundo sui folio "Thomas", extimatum ad quatuor florenos auri. Item Digestum vetus quod incipit in secundo sui folio "annos", extimatum ad tres florenos. Item vnum alium codicem qui incipit in secundo folio "atque obtinet», extimatum ad duos florenos. Item vnum alium codicem qui incipit in secundo folio "ex edicto", extimatum ad vnum florenum. Item "summam Roffredi» que incipit in secundo folio "expeditur», extimatam ad sex grossos cum dimidio. Item vnum pontificale non completum quod incipit in secundo folio "turris», extimatum ad duos florenos. Item vnum collectararium ${ }^{68}$ quod incipit in secundo folio "oue misterii» extimatum ad sex grossos. Item vnum pluiuale coloris viridis. Item vnam casulam cum griffonibus aureis. Item vnum calicem argenti cum sua patena deaurata ponderis vnius marche septem vnciarum ad pondus Curie Romane. Item vnum alium calicem cum sua patena ponderis vnius marche et vnius vncie. Item duo candelabra argenti ponderis duarum marcharum trium vnciarum cum dimidio. Item duo turribula cum catenis argenteis ponderis duarum marcarum trium vnciarum et trium denariorum. Item quatuor fiales quarum tres sunt discooperte ponderis vnius marche cum dimidia minus tribus denariis. Item vnam nauettam cupri. Item duas cruces de argento cum vno cordone de serico ponderis vnius marche cum dimidia vncia. Item quatuor sarcellas argenti pro auribus mulierum ponderis vnius vncie cum dimidia. De quibus omnibus et singulis sic per eundem dominum Bertrandum assignatis ipsum et eius heredes ac sua et eorum bona mobilia et immobilia presencia et futura quittamus, liberamus et absoluimus per presentes. In quorum omnium testimonium presentes litteras fieri fecimus et sigilli officii nostri Camerariatus appensione muniri. Datum Rome apud Sanctum Petrum anno domini millesimo trecentesimo sexagesimo octauo, indictione sexta, die nona mensis Decembris pontificatus sanctissimi in Christo patris et domini nostri domini Vrbani, diuina prouidencia pape quinti anno septimo. Recipiente domino Iohanne Rosseti omnia predicta ${ }^{69}$.

It seems that the dispute between Bishop Demetrio and Urban V and his Curia continued in the following years, because his obligations to the Camera were still not fully paid. On 8 April 1370 the bishop of Rab Chrysogonus de Dominis (1363-1372) was appointed apostolic administrator of Nin diocese, and the officer issued a quittance to Bruno de Georgiis, canon of Rab, who paid the sum of 160 florins on behalf of bishop Chrysogonus due to the Chamber by bishop Demetrio ${ }^{70}$. Demetrio's financial problems continued into the pontificate of Gregory XI (Pierre Roger de Beaufort, 1370-1378). He was still highly indebted with the Camera, and continued to refuse the payment of his dues: [...] cum venerabilis frater noster Demetrius, episcopus Nonensis, camere nostre apostolice in diuersis pecuniarum sumis et rebus aliis legitime teneatur, de quibus eidem camere satisfacere non curauit neque curat! On 14 May 1373 from Avignon Gregory XI had to inform King Louis of Hungary that he had confiscated

\footnotetext{
${ }^{67}$ The medieval editions of the Corpus Iuris Civilis with glossa ordinaria by Accursius was standardized in the thirteenth century in five volumes: I. Digestum vetus containing books 1-24.2; II. Infortiatum containing books 24.3-38; III. Digestum novum containing books 39-50, IV. Codex containing books 1-9, and V. Authenticum (Latin version of 134 out of 168 Novellae), Tres libri (books 10-12), Institutiones, Usus feudorum and several additional texts.

${ }^{68}$ Book of orations to be read during the liturgy of hours.

${ }^{69}$ The integral document was first published in J. NERALIĆ, Put do crkvene nadarbine. Rimska kurija i Dalmacija u 15. stoljé́u. Split, 2007.

${ }^{70}$ Id., Priručnik za istraživanje hrvatske povijesti u Tajnom vatikanskom arhivu od ranog srednjeg vijeka do sredine XVIII. stoljeća. Schedario Garampi, Zagreb 2000, I, p. 424 nº 4478.

ASV, Cam. Ap., Intr. et Exit. 331, f. 26v: [m.s.]: de diuersis. Eodem die [VIII dicti mensis aprilis] recepti fuerunt ibidem [in Auinione] a domino Grisogono episcopo Arbensi, vicario apostolico episcopatus Nonensis, ad manus domini nostri pape nunc existentis, in deductionem et extenuacionem eorum in quibus dominus Demetrius episcopus Nonensis camere apostolice tenetur, soluente per manus Bruni de Georgiis canonici Arbensis. CLX florenos cambii XX. s. monete auinionensis.
} 
revenues of the Nin bishopric, leaving only what was necessary for the bishop's maintenance (fructus episcopatus Nonensis, reseruata congrua sustantacione pro dicto episcopo Nonensi). The revenues would be collected by the Dominican friar Michael, bishop of Skradin $(1356-2)^{71}$. On 8 June of the same year the duke Charles of Durazzo was asked to support bishop of Skradin in his mission relative to the levy of confiscated goods of the Nin diocese ${ }^{72}$.

The last reference on Demetrio in the surviving sources dates from 14 October 1375. According to C. F. Bianchi he was succeded by his nephew - son of his brother Vučina, canon of the Zadar cathedral of St. Anastasia, Ludovico de Matafari. ${ }^{73}$ Following his death in Budim in 1377 the see of Nin was occupied by the archpriest of Zadar cathedral, Demetrius Matafari, nephew of Lodovico Matafari. However, these two Demetrio's successors are not documented in the Vatican sources. One papal letter (dated 17 August 1387) and two cameral entries (dated 14 and 17 March 1393) yielded two names. Firstly, pope Clement VII from Avignon provided Antonio Cernota, rector of St. Mary's ${ }^{74}$, then Johannes episcopus Nonensis promotus anno XI Urbani VI. (1388) ${ }^{75}$ in Rome, paid his obligation to the Camera in March $1393^{76}$.

What seemed to be a case of papal spoil of movable property of a deceased bishop (who died in 1367!) of a minor Dalmatian diocese (erroneously given as Knin instead of Nin!) in the very useful repertory published fourty years ago by professor Daniel Williman, turned to be a completely «different story». Careful study of documentary sources preserved in different archives made possible a reconstruction of another successful fourteenth century ecclesiastical career, intricate political and economical relations of Dalmatian clergy with the Curial administration.

\footnotetext{
${ }^{71}$ SMIČIKLAS, o. c., XIV (1916), p. 522 n 401.

${ }^{72}$ ASV, Reg. Vat. 269, f. 329r; THEINER, o. c., p. 286 n 401; SMIČIKLAS, o. c., XIV(1916), p. 514, n 391.

${ }^{73}$ BIANCHI, o.c., p. 212.

${ }^{74}$ EUBEL, o. c., p. 370.

${ }^{75}$ ASV, Cam. Ap., Oblig. et Sol. 51, f. 56v.

${ }^{76}$ ASV, Cam. Ap., Oblig. et Sol. 59, f. 54v.
} 


\section{NINSKI BISKUP DEMETRIJE MATAFARI (OKO 1315.-1375.) I NJEGOVA AFERA S APOSTOLSKOM KOMOROM: SLUČAJ INVENTARA NJEGOVE POKRETNE IMOVINE}

Slučaj pićanjskoga i ninskoga biskupa Demetrija (oko 1315. - 1375.), člana ugledne i bogate zadarske plemićke obitelji Matafari, i njegovih problema s Apostolskom komorom koja tijekom četrnaestoga stoljeća rezidira u Avignonu, ušao je u europsku crkvenu i kulturno-povijesnu znanost prije četrdesetak godina zahvaljujući Danielu Willimanu. Šturi podatci iz datoteke od oko dvije tisuće slučajeva sakupljeni tijekom višegodišnjih istraživanja fondova Apostolske Komore u Vatikanskome tajnome arhivu, objavljeni u monografijama o papinskome pravu oduzimanja pokretne imovine pokojnih klerika u razdoblju Avinjonskoga ropstva (1316-1415), nisu do sada pobudili pažnju hrvatskih povjesničara. Dio svoje biblioteke ostavio je dominikanskome samostanu u Udinama još početkom 1346. godine; dvadesetak godina kasnije njen je preostali dio, po papinskome pravu rezervacije, otkupljen za Apostolsku komoru. Pored biblioteke zadarskoga plemića koji crkvenu karijeru gradi u Istri i Dalmaciji sredinom četrnaestoga stoljeća, pažnju plijeni i popis njegove pokretne imovine koja je oduzeta kako bi se namirio ogroman dug prema Apostolskoj Komori od preko deset tisuća dukata nastao tijekom gotovo tridesetogodišnje karijere! Dopunjujući svoja istraživanja u Vatikanskome tajnome arhivu s objavljenim dokumentima iz akvilejskih i dalmatinskih arhiva autorica otkriva manje poznate pojedinosti iz života ovoga biskupa koji je svoju karijeru gradio u sjeni daleko poznatijega brata, zadarskoga nadbiskupa Nikole.

Ključne riječi: Apostolska komora, Avinjonsko papinstvo, kolektori, pravo zaplijene, inventar, pokretna imovina, dozvola sastavljanja oporuke, crkvena karijera, Dalmacija, Demetrije Matafari 